Grzegorz Szulczewski

\title{
STUDIUM PRZYPADKU JAKO METODA NAUCZANIA ETYKI BIZNESU
}

\section{Geneza studium przypadku etyki biznesu}

W XIX wieku na wydziale prawa (Law School) Uniwersytetu Harvarda zastosowano metodę rozwiązywania studium przypadku (case study method) w celu sprawdzenia, czy wiedzę przekazywaną na wykładach studenci są w stanie wykorzystać do rozwiązywania skonstruowanych przykładów, które ukazują rzeczywiste problemy decyzyjne powstałe w praktyce prawniczej.

Od momentu wprowadzenia etyki biznesu jako dziedziny akademickiej w połowie lat osiemdziesiątych XX wieku w Harwardzkiej Szkole Biznesu (Harvard Business School) liczba studiów przypadku z etyki biznesu szybko dorównała liczbie zgromadzonych od XIX wieku przypadków na wydziale prawa i lekarskim (Harvard Medical School). Obecnie Harwardzka Szkoła Biznesu (Harvard Law School) dysponuje 2 tys. opracowanych studiów przypadku, które stanowią jej główny „produkt eksportowy”.

Celem studium przypadku etyki biznesu jest, by na odpowiednio dla potrzeb dydaktycznych wypreparowanym z rzeczywistości lub skonstruowanym przykładzie ukazać, na podstawie wskazań analizy etycznej, możliwe rozwiązania problemów moralnych pojawiających się w życiu gospodarczym. Rozwiązujący studium przypadku z zakresu etyki biznesu ćwiczą zdolność diagnozowania i analizowania oraz praktycznego zastosowania teorii i narzędzi etycznych w ich przyszłym życiu zawodowym. Zdobywają również ogromnie cenną dla zarządzających wiedzę negatywną o błędnych rozwiązaniach i związanych z nimi konsekwencjach. Dlatego też prawdziwe staje się twierdzenie, iż rozwiązywanie studium przypadku z zakresu etyki biznesu prowadzi do nabycia lub dalszego rozwoju nie tylko kompetencji zawodowych, ale i moralnych, społecznych oraz kulturowych, a zatem przyczynia się do zapobiegania konfliktom w życiu zawodowym.

Harwardzkie studium przypadku posiada przemyślaną strukturę. Składa się ona ze zwięzłego przedstawienia sytuacji, w tym chronologii i charakterystyki jej sprawców, do których należą również instytucje i korporacje. Następnym krokiem $\mathrm{w}$ rozwiązywaniu studium przypadku z zakresu etyki w biznesie jest ukazanie, 
jakie problemy etyczne wynikają z rozwoju opisanej sytuacji. Dalej przechodzi się do poszukiwania rozwiązań tych problemów poprzez przedstawienie możliwych sposobów działania. Następnie w kontekście etyki rozważa się zaproponowane opcje działania i odnoszące się do nich uzasadnienia. Po wyborze najlepszego, w sensie etycznym, rozwiązania przedstawia się plan przeprowadzenia działania wskazanego w wyniku analizy etycznej.

\section{Charakterystyka studium przypadku z zakresu etyki biznesu}

Od czasu oryginalnego zastosowania metody studium przypadku w etyce biznesu znacznie rozwinęła się metodologia związana $\mathrm{z}$ jego budową i jednocześnie $\mathrm{z}$ analizą. W literaturze fachowej i powstałej na potrzeby dydaktyki znajdziemy wiele projektów struktury studium przypadku i propozycji jego analizy.

Wskazują one na potrzebę, po zapoznaniu się z opisem i wydaniu spontanicznego osądu moralnego, powtórnego sięgnięcia do opisu i dokonania dokładnej jego analizy, tym razem analizy etycznej. Przy czym sugeruje się przeprowadzenie trójstopniowej analizy etycznej przez osobę rozwiązującą studium przypadku. Najpierw powinna ona ujawnić to, co wynika $\mathrm{z}$ opisu, a nie jest w nim bezpośrednio zawarte, np. zobowiązania moralne pomiędzy sprawcami zdarzeń. Następnie mamy za zadanie przedstawić własną argumentację na rzecz preferowanego rozwiązania, sprawdzając, czy jest koherentna i do wprowadzenia w życie, a potem dokonać jej oceny w świetle znanych narzędzi etycznych i teorii moralnych. Kiedy ostatecznie zdecydujemy się po analizie etycznej na wybór jednego z rozwiązań, należy je porównać z rozwiązaniem, jakie podsuwał spontaniczny osąd i zastanowić się, dlaczego ewentualnie propozycje rozwiązań problemów etycznych różnią się pomiędzy sobą.

Ten zabieg uświadomi nam znaczenie samej refleksji etycznej w znajdowaniu najlepszych rozwiązań problemów moralnych, jakie niesie ze sobą działalność gospodarcza.

W zależności od celu wytyczonego przez piszących studium przypadku wyróżniamy kilka ich rodzajów.

Studium przypadku może polegać na położeniu nacisku na poszukiwanie informacji, które są potrzebne do podjęcia właściwej decyzji w sensie moralnym. Kształci ono wtedy zdolności analityczne. 
Inny rodzaj studium przypadku polega na lokalizacji problemów moralnych i ich wyrażaniu za pomocą kategorii etycznych. Mamy wówczas do czynienia z kształceniem zdolności diagnostycznych.

Istnieją też studia przypadków, w których kładzie się nacisk przede wszystkim na przedstawienie i etyczne uzasadnienie rozwiązań idących na tyle daleko, że poddaje się krytyce przedstawione rozwiązania. W tym przypadku mamy do czynienia $\mathrm{z}$ kształceniem zdolności praktycznego zastosowania etyki w podejmowaniu decyzji w gospodarce.

Z kolei ze względu na typ rozważanego zagadnienia moralnego, jakie opisuje studium przypadku, mamy do czynienia ze studium przypadku rozpatrującym problem moralny, co do którego jesteśmy w stanie znaleźć kilka rozwiązań i wybrać jedno, spełniające w pełni wymogi stawiane przez etykę. Mamy wtedy do czynienia ze studium problemowym.

W trakcie rozwiązywania studium przypadku możemy również spotkać się z dylematem moralnym. Oznacza on sytuację, w której musimy dokonać wyboru pomiędzy zachowaniem reguł, bądź wartości uznanych jednocześnie przez nas za równie ważne. Mamy wtedy do czynienia ze studium dylematu moralnego.

Istnieją również sytuacje opisywane w studium przypadku, które stawiają nas przed wyborem jedynie mniejszego zła lub pozostawiają nam wybór przyjęcia strategii minimalizacji szkód i strat i wzięcie na siebie odpowiedzialności za takie rozwiązania. Mamy wtedy do czynienia ze studium tragicznego wyboru.

Występują także różne typy studium przypadku jeśli chodzi o rolę, jaką pełnić ma sama etyka.

Istnieją studia przypadków, w których oczekuje się rozwiązania powstałego wcześniej problemu moralnego zgodnie z zasadami i normami etycznymi.

Są też znane studia przypadków, w których wprowadzenie wskazań etycznych pełni funkcję prewencyjną, a mianowicie zapobiega krzywdzie czy powstaniu szkody moralnej.

Istnieją też studia przypadków, w których refleksja etyczna służy do zajęcia stosownego stanowiska w sporze lub konflikcie moralnym.

Pamiętajmy przy tym również, że występuje wiele przypadków nienależących do etyki biznesu, w których zbędne jest stosowanie norm i zasad etycznych, gdyż wymagane rozwiązania nie odnoszą się w żaden sposób do dobra i zła moralnego. Istnieje bowiem cały ogromny obszar decyzji o charakterze ekonomicznym czy technologicznym niepodlegających ocenie moralnej i tym samym niewymagających analizy etycznej.

Właśnie $\mathrm{w}$ trakcie rozwiązywania studium przypadku z zakresu etyki biznesu nabieramy zdolności rozpoznania, kiedy rzeczywiście analiza etyczna decyzji 
gospodarczych jest konieczna, a kiedy zbędna. Jednocześnie praktyczne zastosowanie etyki do kwestii gospodarczych pozwala nam nauczyć się trudnej sztuki łączenia wymogów płynących z zasad etycznych z koniecznościami natury ekonomicznej.

W założeniu twórców studiów przypadku z zakresu etyki biznesu powinniśmy nabyć, po wielokrotnym ich rozwiązywaniu, zdolności do rozpoznania, jakie zasady etyczne są fundamentalne i tym samym nie można ich łamać pod żadnym warunkiem, nawet ze względu na konieczności ekonomiczne.

Przeciwnicy nauczania etyki biznesu na podstawie studium przypadku podnoszą zarzuty, iż rozwiązania zastosowane w studium przypadku nie uwzględniają ryzyka utraty pracy, majątku czy dobrego imienia, co może dotyczyć osoby podejmującej decyzje w realnym życiu gospodarczym. O wiele łatwiej jest zdecydować się bowiem na rygorystyczne rozwiązanie broniące za wszelką cenę reguł moralnych w sytuacji bycia studentem rozwiązującym studium przypadku niż przez przedsiębiorcę czy pracownika uczestniczącego w realnym życiu gospodarczym.

Problemem równie często podnoszonym przez krytyków wprowadzania metody studium przypadku do nauczania etyki biznesu jest kompleksowość zjawisk gospodarczych. Do specyfiki studium przypadku z zakresu gospodarki należy faktycznie wysoka złożoność relacji, jakie przyczyniają się do powstania rozpatrywanych zjawisk. W samej bowiem gospodarce będącej dziedziną oddziaływań społecznych występuje wiele sprzężeń zwrotnych i reakcji równoczesnych polegających na zmianach strategii działania ze względu na decyzje, jakie podejmują partnerzy biznesowi. Zmusza to piszących studium przypadku do selektywnego podejścia, polegającego na abstrahowaniu od części zachodzących interakcji w gospodarce, gdyż inaczej nie moglibyśmy wydać jednoznacznej oceny moralnej, ponieważ ciągle ujawniałyby się nowe fakty, budząc wątpliwości co do trafności przyjętego rozwiązania.

Dlatego pierwszym problemem, przed którym stajemy zarówno przy wyborze materiałów do pisania studium przypadku, jak i samemu rozwiązując studium przypadku, jest właściwe odniesienie do opisu sytuacji zawartego w studium przypadku. Chodzi mianowicie o to, by wszelki opis zdarzeń zawierał przede wszystkim najistotniejsze szczegóły, a osoby zapoznające się z opisem były z kolei zdolne do ich odnalezienia, w z konieczności szerszej narracji, jaką narzuca opis w studium przypadku.

W celu ułatwienia rozwiązania studium przypadku z zakresu etyki biznesu można wykorzystać możliwości, jakie daje nam sama filozofia. Pozwoli to na zwiększenie naszej zdolności zarówno do właściwego odczytania opisu, jak i do zrozumienia sytuacji problemowej oraz jej właściwej analizy etycznej, a także dokonania wnikliwszej oceny możliwych rozwiązań studium przypadku.

Na początek przydatna staje się metoda fenomenologiczna, a szczególnie proponowana przez nią redukcja ejdetyczna pozwalająca na ujęcie istoty zjawisk. 
Z kolei hermeneutyka pozwala na interpretację opisywanych zdarzeń i ich zrozumienie.

Filozofia analityczna przyczynia się do uściślenia znaczeń pojęć, które potrzebne są do przeprowadzenia analizy, a metoda sokratejska ukazuje możliwość zadawania określonych pytań w celu wydawania sądów etycznych.

Filozofia dialogu $\mathrm{z}$ kolei wspiera metodycznie poszukiwanie alternatywnych propozycji rozwiązań, a metaetyka może być pomocna w badaniu stopnia uzasadnienia wykorzystywanych formuł etycznych.

Natomiast metoda dialektyczna przydaje się w sytuacji, w której w studium przypadku mamy do czynienia z opisem konfliktu i musimy podjąć próbę jego przezwyciężenia, opierając się na dorobku etyki.

Gdy spojrzymy z pewnego dystansu na nasze rozwiązywanie studium przypadku, ujawni się nam wówczas interesująca prawidłowość. Na początku, zapoznając się ze studium przypadku, sytuacja w nim opisana jest przez nas, jak już wspomnieliśmy, oceniana moralnie w sposób spontaniczny. Ta ocena może nie być do końca zwerbalizowana i objawiać się np. zakłopotaniem moralnym czy skrupułami, jakie budzą w nas najłatwiej narzucające się rozwiązania.

Dlatego zaczynamy zawsze od poczucia moralnego lub wydania spontanicznego sądu moralnego, potem prowadzimy refleksję etyczną związaną z poszukiwaniem właściwych decyzji, by ostatecznie zająć stanowisko moralne w kwestii przedstawionej $\mathrm{w}$ studium przypadku. Mamy zatem do czynienia z sekwencją: moralność-etyka-moralność.

\section{Zastosowanie etyki do rozwiązywana studium przypadku z zakresu etyki biznesu}

Jeśli chodzi o wykorzystanie teorii i kategorii etycznych, to możemy wykorzystać refleksję etyczną prowadzoną nieprzerwanie od czasów starożytności do dnia dzisiejszego, czyli przez prawie 2500 lat. W celu uporządkowania teorii i kategorii etycznych można pokusić się o ich schematyczne przedstawienie. Stanowić one będą zbiór narzędzi etycznych służących do rozwiązywania studium przypadku z zakresu etyki biznesu. Jest oczywiste, że ze względu na całe bogactwo możliwości stosowania etyki do analizy studium przypadku nigdy nie będziemy w stanie przedstawić wszystkich teorii i kategorii etycznych. Mogący ulec rozszerzeniu schemat zasobów etycznych możliwych do wykorzystania przy analizie studium przypadku przedstawiono na rysunku 1. 


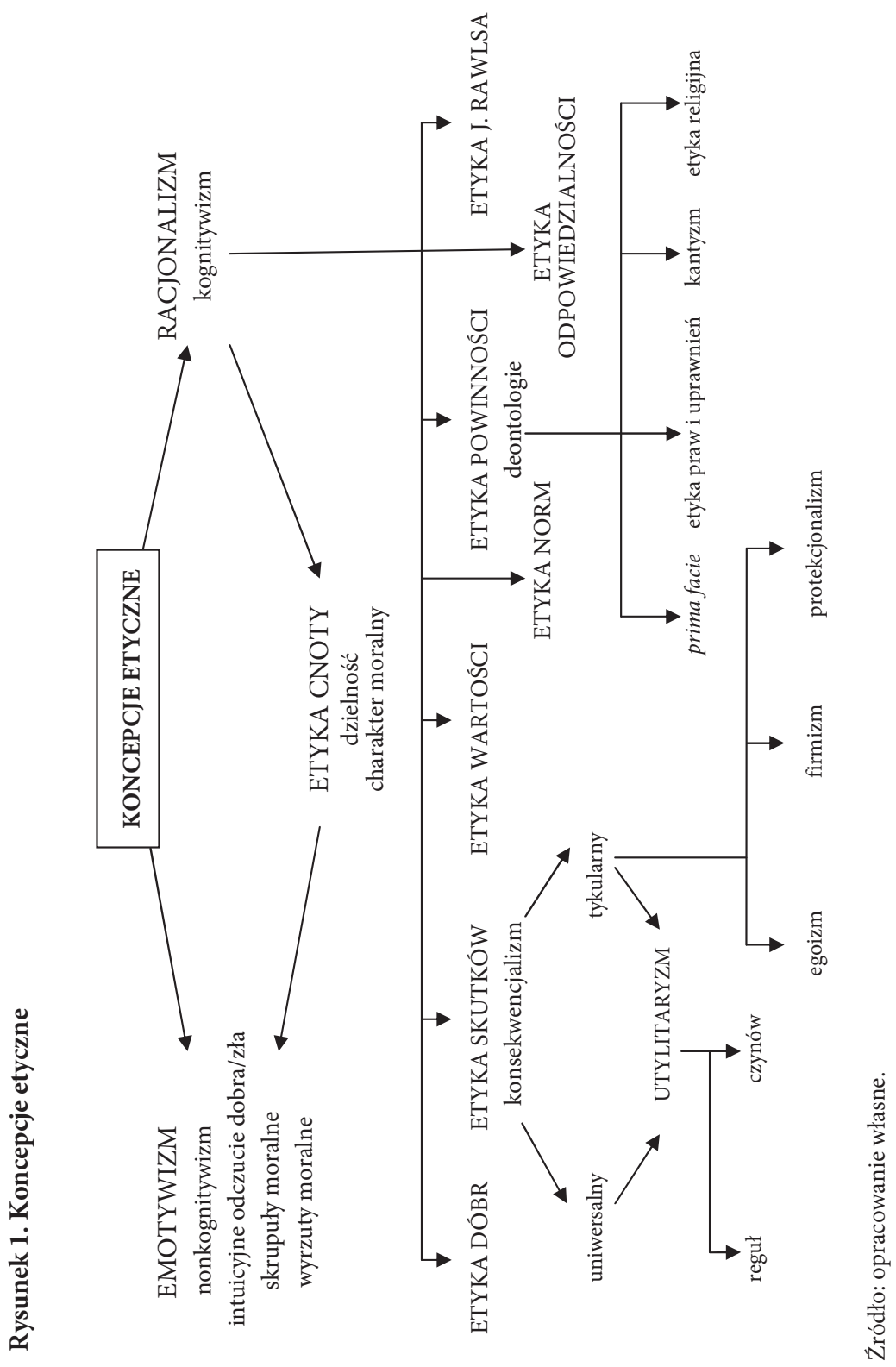


Pierwszoplanowym czynnikiem mającym wpływ na rozwiązanie zadań stawianych przez studium przypadku jest poziom moralny osób podejmujących się tego przedsięwzięcia. Nie każdemu jest dane dokonać przejścia od intuicyjno-uczuciowej oceny moralnej do poszukiwania wskazówek etycznych w celu rozwiązania rysującego się zagadnienia moralnego, jakie stawia studium przypadku. W większości jednak znajdujemy się na poziomie rozwoju moralnego, który pozwala nam, by $\mathrm{w}$ przedstawionej sytuacji $\mathrm{w}$ studium przypadku emocjonalnie określić to, co słuszne, i to, co wypada - i to właśnie umożliwia nam rozpoczęcie poszukiwania rozwiązań zapobiegających sytuacji, która wedle nas jest nie do przyjęcia.

Przy czym sam poziom moralny może kształtować środowisko, w którym przebywamy. Wcześniej taką rolę pełniły autorytety i tradycja, a źródłem ich utrwalania i propagowania były instytucje takie jak rodzina, szkoła, państwo, kościół. Obecnie znaczną rolę odgrywają media, a na kształt poglądów moralnych wpływa teraz w większym stopniu grupa rówieśnicza, a ostatnio firma czy też wielka korporacja.

Podkreślmy jeszcze raz, że od poziomu moralnego zależy jednak, czy osoby podejmujące się rozwiązania zadań stawianych przez studium przypadku w ogóle rozpoznają, iż mamy do czynienia z problemem moralnym i dostrzegą szansę na posłużenie się dorobkiem etyki.

Nie tylko jednak do rozwiązywania studium przypadku z etyki biznesu wymagany jest pewien poziom moralny, ale z drugiej strony właśnie studium przypadku stanowi dobrą pomoc w edukacji moralnej podejmującej się prób wznoszenia na wyższy poziom moralny, który charakteryzuje zdolność świadomego zastosowania zasad i norm etycznych.

Natomiast dla osób, których grono niestety nie maleje, a mianowicie osób cynicznych czy dotkniętych anomią moralną, rozwiązania studium przypadku ukazują, jak niekiedy niewiele potrzeba, by przy wykorzystaniu dorobku etyki podjąć decyzję właściwą z moralnego punktu widzenia.

Model rozwoju moralnego stworzony przez L. Kohlberga przedstawia, jakie docelowe rozwiązania preferują poszczególne osoby znajdujące się na różnych poziomach rozwoju moralnego. 
Tabela 1. Model rozwoju moralnego L. Kohlberga

\begin{tabular}{|c|c|c|c|c|}
\hline $\begin{array}{l}\text { Etap rozwoju } \\
\text { moralnego }\end{array}$ & $\begin{array}{l}\text { Motyw uzasadnienia } \\
\text { podejmowanych } \\
\text { działań }\end{array}$ & $\begin{array}{c}\text { Zasada } \\
\text { podejmowanego } \\
\text { działania }\end{array}$ & $\begin{array}{l}\text { Charakterystyka dobra } \\
\text { jako celu działania }\end{array}$ & $\begin{array}{c}\text { Uwzględniane } \\
\text { w trakcie działania }\end{array}$ \\
\hline \multirow[t]{2}{*}{ Podstawowy } & \multirow[t]{2}{*}{ egoistyczny } & \multirow[t]{2}{*}{$\begin{array}{l}\text { dobre tylko to, } \\
\text { co jest dobre dla mnie }\end{array}$} & $\begin{array}{l}\text { dobrem korzyść bez } \\
\text { narażania się na karę }\end{array}$ & zakaz \\
\hline & & & $\begin{array}{l}\text { dobrem korzyść } \\
\text { w postaci nagrody }\end{array}$ & obietnica nagrody \\
\hline \multirow[t]{2}{*}{ Środkowy } & \multirow[t]{2}{*}{ konwencjonalny } & \multirow[t]{2}{*}{$\begin{array}{l}\text { dobre to, co jest dobre } \\
\text { dla wspólnoty }\end{array}$} & $\begin{array}{l}\text { dobre to, co dobre } \\
\text { dla mojej grupy }\end{array}$ & obyczaje \\
\hline & & & $\begin{array}{l}\text { dobre to, co dobre } \\
\text { dla wszystkich ludzi } \\
\text { podobnych do mnie }\end{array}$ & zasady gry fair play \\
\hline \multirow[t]{2}{*}{ Dojrzały } & \multirow[t]{2}{*}{ etyczny } & \multirow[t]{2}{*}{$\begin{array}{l}\text { dobre to, co jest dobre } \\
\text { dla ludzkości }\end{array}$} & $\begin{array}{l}\text { dobre to, co dobre } \\
\text { dla społeczeństwa }\end{array}$ & $\begin{array}{l}\text { kodyfikacje prawne } \\
\text { i etyczne }\end{array}$ \\
\hline & & & $\begin{array}{l}\text { dobre to, co dobre } \\
\text { dla wszystkich ludzi }\end{array}$ & $\begin{array}{l}\text { inteligencja moralna } \\
\text { i głos sumienia }\end{array}$ \\
\hline
\end{tabular}

Źródło: opracowanie własne na podstawie koncepcji L. Kohlberga zawartej w: L. Kohlberg, R. Mayer, Rozwój jako cel wychowania, w: Spory o edukację, red. Z. Kwieciński, L. Witkowski, IBE, Warszawa 1993.

Niezmiernie ważne jest zatem, by osiągnąć fazę dojrzałą rozwoju moralnego. Z tego względu należy rozwijać inteligencję moralną, dzięki której natrafimy na właściwe rozwiązanie zagadnień postawionych $\mathrm{w}$ studium przypadku. ${ }^{1}$

\section{Modele rozwiązywania studium przypadku z zakresu etyki biznesu}

W celu ułatwienia prac nad rozwiązaniem studium przypadku możliwe jest załączenie instrukcji przedstawiającej kolejne kroki postępowania.

1 Por. D. Lennick, F. Kiel, Inteligencja moralna, Purana, Wrocław 2007, s. 46. Podkreślmy wagę rozwijania inteligencji moralnej: Inteligencja moralna kieruje najwyższym etapem rozwoju moralnego, pozwala rozpoznać sytuację wymagającą decyzji o charakterze moralnym oraz dzięki niej jesteśmy w stanie wykorzystać wiedzę z zakresu etyki służącą do prawidłowej oceny moralnej. Stanowi ona umiejętność wyznaczania sobie takich celów i dokonywania takich wyborów, by były zgodne z poszanowaniem zasad moralnych. Dzięki jej działaniu osiągamy sztukę pogodzenia własnych aspiracji z akceptowalnym w sensie moralnym układem wartości. Ocenia ona, w jakim stopniu nasze cele i zachowania są zgodne z naszym kompasem moralnym. Jej działanie zapewnia wierność sobie. Pozwala nam zatem odpowiedzieć na pytanie, na ile nasze życie wewnętrzne cechują: konsekwencja, uczciwość, spójność, brak hipokryzji. Inteligencja moralna wiąże się również ze zdolnością do przyznawanie się do błędów. Stanowi umiejętność kompromisu i samowybaczania, a także wybaczania innym. Posiadając inteligencję moralną, jesteśmy „zdolni do godzenia ze sobą planów, działań i wartości etycznych”. 
Oto przykładowe instrukcje, które mogą być również podstawą zadania egzaminacyjnego polegającego na rozwiązaniu studium przypadku.

\section{Instrukcja 1}

Studium przypadku może dotyczyć zarówno wydarzeń prawdziwych, w tym stanowić opis własnych doświadczeń, opis relacji usłyszanych, jak i treści artykułów prasowych, ale też może dotyczyć zdarzeń będących fikcją literacką bądź filmową lub wytworem własnej inwencji. Dopuszczalne jest zatem zamieszczanie w studium przypadku fragmentów dzieł literackich, opisów filmów czy własnych wymyślonych opisów.

1) Należy opisać przypadek działania gospodarczego, które rozpatrywane z punktu widzenia:

a) rachunku ekonomicznego jest oceniane jako opłacalne,

b) prawa nie jest zabronione,

c) etyki (preferowanych wartości, obowiązujących norm, imperatywów i zasad moralnych) budzi wątpliwości co do jego godziwości.

2) Następnie trzeba dokonać analizy, dlaczego mimo efektywności i legalności to działanie budzi wątpliwości moralne. ${ }^{2} \mathrm{~W}$ analizie powinniśmy wskazać, jakie zasady etyczne zostają naruszone.

Oto możliwy model etycznego działania gospodarczego opartego na „potrójnym E”:

E1 Efektywność działania - stopień osiągania zamierzonego celu.

E2 Ekonomiczność działania - wprowadzanie w życie zasady minimax: użycie jak najmniejszej ilości środków, aby osiągnąć dany cel lub przy danych środkach osiągnięcie jak najlepszych efektów; wyraża się ona w oszczędności i wydajności.

E3 Etyczność działania w trakcie jego realizacji związana jest $z$ tym, że:

a) nie są naruszane normy uznane;

b) nie tylko nie dochodzi do naruszania norm i wartości, ale również działanie gospodarcze zapobiega ich naruszaniu lub generuje wartości wyższe; trzeba jednak pamiętać, iż zawsze tam, gdzie chodzi o „wielkie pieniądze”, czy tam, gdzie istnienie firmy jest zagrożone, rodzi się pokusa podejmowania działań nieetycznych; nawet jeśli przekroczenie zasad moralnych nastąpi w dobrej wierze dla uratowania firmy i nie wyjdzie poza wąski krąg pracowników firmy,

2 W. Gasparski pisze: „Działalność gospodarcza, w tym działalność firm nominowanych do uznania ich za Filary Polskiej Gospodarki w regionach ich funkcjonowania, dokonywana jest ze względu na ich efektywność, ekonomiczność i etyczność, czyli tzw. potrójne E. Działania gospodarcze można poddawać analizie ze względu na każdy z tych trzech wymiarów z osobna. Jest natomiast wadliwe projektowanie oraz wykonywanie działań gospodarczych, tj. ich synteza, bez brania pod uwagę łącznie "potrójnego E«, tj. wszystkich trzech wymienionych charakterystyk działania”. „Decydent \& Decision Maker” styczeń $2008 \mathrm{nr}$ 74, http://www.decydent.pl/archiwum/wydanie_17/decyzje-i-etyka_102.html 
to jednak czynione zło może wcześniej czy później prowadzić do wyrzutów sumienia lub nawet dezintegracji osobowości.

Możemy też przedstawić bardziej złożoną instrukcję rozwiązywania studium przypadku.

\section{Instrukcja $\mathbf{2}^{3}$}

I. Opis przypadku

1) Identyfikacja problemu

a) Nazwanie zjawiska w kategoriach biznesowych. Co było przyczyną powstania problemu?

b) Wybierz trzy narzędzia etyczne do opisu problemu.

c) Dokonaj opisu problemu w kategoriach etycznych.

2) Geneza problemu

a) Kiedy zauważono problem?

b) Kto jest odpowiedzialny za tę część przedsiębiorstwa, gdzie pojawił się problem?

c) Jakie elementy infrastruktury etycznej firmy zostały naruszone?

3) Znaczenie problemu

a) Jakie znaczenie ma ten problem dla funkcjonowania firmy?

4) Prognozy w razie niepodjęcia żadnych działań

a) Prognoza optymistyczna - problem sam się rozwiąże. Czy mimo to są racje za podjęciem działań $\mathrm{w}$ celu rozwiązania tego problemu?

3 Inspiracją do napisania instrukcji było „Dwanaście pytań służących określeniu etycznych postaw decyzji gospodarczych" zawartych w: L.L. Nash, Etyka bez kazań, w: Etyka biznesu. Z klasyki wspótczesnej myśli amerykańskiej, red. L.V. Ryan CSV, J. Sójka, W drodze, Poznań 1997, s. 250-271.

„Dwanaście pytań służących określaniu etycznych podstaw decyzji gospodarczych:

1) Czy dokładnie określiłeś problem?

2) Jak określiłbyś ten problem, stojąc po drugiej stronie?

3) Jak w ogóle doszło do takiej sytuacji?

4) Wobec kogo i wobec czego starasz się być lojalny jako osoba i jako pracownik spółki?

5) Jakie masz zamiary, podejmując taką decyzją?

6) Jak mają się te zamiary do możliwych rezultatów?

7) Kogo mogłaby skrzywdzić twoja decyzja lub twoje działanie?

8) Czy masz możliwość omówienia problemu z zainteresowanymi stronami przed podjęciem decyzji?

9) Czy jesteś pewien, że twoje obecne stanowisko będzie również aktualne w dłuższym okresie?

10) Czy możesz, bez żadnych skrupułów, wyjawić swoją decyzję lub działania bezpośredniemu przełożonemu, dyrektorowi naczelnemu, całej radzie dyrektorów, swojej rodzinie, społeczeństwu jako całości?

11) Jaka będzie symboliczna wymowa twojego działania, jeśli zostanie ono właściwie zrozumiane? Jaka, jeśli zostanie zrozumiane źle?

12) Pod jakim warunkiem zgodziłbyś się na uczynienie wyjątku i rezygnację ze swojego stanowiska?”. 
b) Prognoza pesymistyczna - niebezpieczeństwo kryzysu organizacji, jeśli nie zostaną podjęte odpowiednie kroki. Na czym będzie polegał kryzys i jakiego będzie rodzaju?

II. Analiza etyczna problemu

1) Wybierz trzy narzędzia do analizy etycznej problemu.

2) Dokonaj analizy etycznej problemu, opierając się na tych trzech narzędziach.

III. Propozycje rozwiązania

1) Przedstaw, jeśli to możliwe, alternatywne propozycje rozwiązania, podając ich uzasadnienie.

2) Czy są to realne rozwiązania?

3) Przedstaw zamierzone i niezamierzone skutki oddziaływań.

4) Jakie będą koszta, w tym koszta etyczne, proponowanych rozwiązań problemu?

5) Zastosuj wybrane narzędzia etyczne do wyboru jednego z rozwiązań i podaj uzasadnienie.

Możliwe jest również opracowanie, na podstawie bogatej literatury i dostępnych w internecie materiałów, listy szczegółowego postępowania związanego z rozwiązywaniem studium przypadku.

\section{Instrukcja 3}

\section{Lokalizacja i określenie problemu}

I. Wstępne ujęcie problemu

1) Najpierw postaraj się dostrzec problem.

2) Przedstaw najbardziej ogólnie problem.

3) Zadaj pytania naprowadzające do jego bliższego określenia:

a) Z czego wynika problem: z błędu, zaniechania, bądź okoliczności niezależnych?

b) Czy problem związany jest bezpośrednio z działalnością biznesową, czy też wynika $z$ działań poza rolą organizacyjną?

c) Czy możesz wysłuchać zainteresowanych osób, których dotyczy problem?

II. Określ bardziej szczegółowo, na czym polega problem.

1) Rozpatrz ten problem ze swojej perspektywy.

2) Jak określiłbyś problem, stojąc po przeciwnej stronie?

3) Jak określisz go z perspektywy relacji: ja-ty, ja-my, pracownik-organizacja, z pespektywy wspólnoty: społeczności lokalnej, społeczeństwa, a ostatecznie z perspektywy ludzkości? 
III. Rozpatrz ten problem w kontekście ponoszenia odpowiedzialności.

1) Jakie działania zawarte w opisie studium przypadku podlegają odpowiedzialności moralnej?

2) Za jakie skutki trzeba będzie ponosić odpowiedzialność, jeśli nie podejmiemy żadnych działań?

3) Wobec kogo będziemy ponosić odpowiedzialność?

4) Przed kim będziemy ponosić odpowiedzialność?

5) Kto będzie ponosić odpowiedzialność za decyzję, w tym odpowiedzialność bezpośrednią i pośrednią?

\section{Analiza etyczna postawionego zagadnienia}

IV. Dokonaj analizy, opierając się na wybranych narzędziach etycznych.

1) Uzasadnij, dlaczego zastosowałeś dane poglądy etyczne do analizy etycznej.

2) Uświadom sobie, z jakimi ograniczeniami musisz się liczyć, podejmując decyzję. Czy są to ograniczenia ze strony: prawa, środowiska biznesu, ograniczenia technologiczne, ekonomiczne, z zakresu kultury organizacyjnej, w tym ograniczenia wypływające z deklaracji etycznych zawartych w dokumentach firmy, a może ograniczenia narzucane przez kulturę regionalną bądź narodową?

\section{Proces podejmowania decyzji}

V. Zastanów się nad możliwą decyzją.

1) Czy możliwe jest jedno dobre rozwiązanie?

2) Spróbuj określić różne rozwiązania ze względu na odmienne poglądy etyczne.

3) Określ cele, jakie chciałeś osiągnąć, podejmując decyzję.

4) Jak proponowane rozwiązanie ma się do więzów lojalności łączących cię z osobami, które mają je wdrożyć?

5) Zastanów się, jakie rozumienie dobra zakładasz, preferując konkretne rozwiązanie problemu postawionego w studium przypadku: Czy uznajesz dobro jednostki i zasadę egoizmu oświeconego, czy może zasady etyki społecznej - zasadę solidarności społecznej kładącej nacisk na pomoc i wspieranie słabszych i biednych, zasadę chrześcijańskiej subsydiarności podkreślającej potrzebę poszukiwania rozwiązań przez samych sprawców problemów i nakazującą poszanowanie ich autonomii, a może przede wszystkim uznajesz zasadę społecznej pomyślności zwracającej uwagę na preferowanie działań przyczyniających się do dobrobytu wspólnoty lub też najważniejsze jest dla ciebie kierowanie się zasadą służebności wskazującą na wzrost odpowiedzialności osób, które zarządzają innymi osobami lub powierzonymi im dobrami? 
6) Jakie wartości były celem działania doprowadzającego do powstania opisanej w studium przypadku sytuacji i jakie ewentualnie wartości mogą być naruszone?

7) Jak mają się do przestrzegania norm wybrane środki proponowane do urzeczywistniania celów?

VI. Przed podjęciem ostatecznej decyzji

1) Wymień etyczne, ekonomiczne i prawne argumenty „za” i „przeciw” przyjęciu każdego z rozwiązań.

2) Zastanów się, kto zyska, a kto straci na danej decyzji i zbadaj, czy to będzie zgodne $\mathrm{z}$ twoim poczuciem sprawiedliwości. ${ }^{4}$

3) Przed ostatecznym podjęciem decyzji postaraj się spojrzeć na nią oczami innych. Zastanów się, jak postąpi w danej sytuacji osoba, którą cenisz za jej profesjonalizm oraz osoba, która jest dla ciebie autorytetem.

4) Weź pod uwagę, jak będziesz się czuł po podjęciu tej decyzji.

a) Czy będziesz mógł sobie spojrzeć prosto w oczy?

b) Czy nie będziesz czuł się nieswojo w stosunku do kolegów?

c) Czy bez obaw powrócisz do domu, gdy rodzina dowie się, co zadecydowałeś?

d) Czy szef będzie zadowolony, gdy się dowie o twej decyzji?

e) Czy sen o tym, jak udzielasz wywiadu telewizyjnego o swojej decyzji, nie będzie koszmarem?

5) Jak mają się intencje do możliwych rezultatów decyzji?

6) Czy stopień ryzyka nieudanej realizacji decyzji nie jest zbyt duży?

7) Czy sam wybór rozwiązania i sposób realizacji decyzji będzie równie dobrze oceniony w dłuższym okresie?

8) Czy jesteś w stanie zrezygnować ze swojej decyzji?

9) Czy warunek doprowadzający do zmiany decyzji jest możliwy do akceptacji?

10) Jeśli tak, to który wybór jest lepszy i dlaczego?

VII. Po rozważeniu wszystkich wskazanych kwestii przedstaw własne rozwiązanie.

${ }^{4} \mathrm{~W}$ tym miejscu należy wykorzystać koncepcję interesariuszy. Oto przykład:

\begin{tabular}{|l|l|l|l|}
\hline \multicolumn{1}{|c|}{ Studium przypadku } & Kogo z interesariuszy dotyczy & Korzyści, jakich doświadczają & Szkody, jakich mogą doznać \\
\hline Rozwiazanie 1 & & & \\
\hline Rozwiązanie 2 & & & \\
\hline Rozwiązanie 3 & & & \\
\hline
\end{tabular}

Źródło: F.J.H. Kaminski, Methodik des Ökonomieunterrichts, Klinkhardt, Bad Heilbrunn 1999, s. 14. 


\section{Ocena etyczna podjętej decyzji}

VIII. Określ koszty moralne podjętej decyzji, udzielając odpowiedzi na poniższe pytania.

1) Czy twoja decyzja nie narusza złotej reguły?

2) Czy twoje intencje są zgodne $z$ nakazem moralnym wypełnienia obowiązków? W celu odpowiedzi:

a) Zastosuj imperatyw kategoryczny.

b) Zastosuj zasadę prima facie.

c) Zbadaj, czy wypełniono obowiązki konieczne przed niezupełnymi, np. życzliwości. ${ }^{5}$

d) Zastosuj imperatyw praktyczny.

3) Czy twoja decyzja dokona się z poszanowaniem praw moralnych? W celu odpowiedzi rozważ, czy swoją decyzją nie naruszysz praw człowieka.

4) Czy nie nadużyjesz zaufania, jakim darzy twą profesję społeczeństwo?

5) Zastosuj test pomyślności (utylitaryzm), czyli ustal, jakie korzyści i jakie szkody przyniosą twoje działania.

6) Zbadaj, czy przestrzegasz reguł społecznie korzystnych, czy osiągasz sprawiedliwy rozkład korzyści i szkód oraz czy z rozwiązania studium przypadku wynika, że przywiązujesz większą wagę do szkód niż korzyści.

IX. Następnie spójrz na decyzję od strony etyki biznesu.

1) Zbadaj, które z możliwych rozwiązań jest do przyjęcia na gruncie etyki biznesu.

2) Zastanów się, które rozwiązanie jest najlepsze na gruncie etyki biznesu i dlaczego.

${ }^{5}$ G.D. Chryssides, J.H. Kaler, Wprowadzenie do etyki biznesu, PWN, Warszawa 1999. W tej książce na stronie 114 znajdujemy cenne wskazówki dla rozwiązania studium przypadku:

„(A) Zalecenia dotyczące pomyślności:

Oblicz, jakie pożytki i jakie szkody przynoszą dane działania (i komu).

Staraj się przestrzegać reguł społecznie korzystnych!

Staraj się osiągać sprawiedliwy rozkład korzyści i szkód!

Przywiązuj większą wagę do szkód niż do korzyści!

(B) Zalecenia dotyczące obowiązków:

Zbadaj motywy działania, by określić, czy zasługują na uznanie moralne.

Zastosuj do motywów test uniwersalizacji, który pomaga w określeniu ogólnych obowiązków moralnych. Odróżniaj obowiązki faktyczne od obowiązków prima facie za pomocą testu względnej ważności.

Odróżniaj obowiązki zupełne od obowiązków niezupełnych za pomocą testu występowania odpowiednich praw człowieka.

Rozpoznaj specyficzne obowiązki wypływające z roli społecznej.

(C) Zalecenia dotyczące praw:

Zastosuj test szacunku dla osoby, który pomaga określić podstawowe prawa moralne.

W przypadku konfliktu praw użyj testu względnej ważności.

Rozpoznaj specyficzne prawa wypływające z roli społecznej”. 
3) Określ ocenę prawną rozważanych do wyboru działań. W przypadku, gdy preferowane przez ciebie działanie może naruszyć prawo, zastanów się, czy z etycznego punktu widzenia rzeczywiście istnieją dobre racje do podjęcia działania.

4) Czy wybór jest zgodny z twoim systemem wartości?

5) Czy decyzja nie narusza wartości wyznawanych przez firmę?

6) Czy któryś z elementów programów etycznych firm nie wskazuje na inne rozwiązanie?

\section{Rola studium przypadku w edukacji i samoedukacji}

Te trzy instrukcje ukazują możliwości nie tylko operowania samym studium przypadku jako metodą sprawdzania rezultatów edukacji z zakresu etyki w biznesie, ale również na ich podstawie możliwe jest ułożenie planów samego przedmiotu „etyka w biznesie”.

Studium przypadku przedstawione w trakcie zajęć akademickich oraz polecone na egzaminie z etyki biznesu wydaje się być lepszym rozwiązaniem niż wprowadzanie testów, i to z dwóch względów.

Po pierwsze, student dokonuje samodzielnego rozwiązania studium przypadku, a nie wybiera pośród możliwości, jakie przedstawił mu wykładowca, do czego sprowadza się rola studenta rozwiązującego testy.

Po drugie, konieczność dokonania indywidualnych rozstrzygnięć i własnego uzasadnienia eliminuje główną dolegliwość egzaminowania, a mianowicie ściąganie.

Studium przypadku z zakresu etyki w biznesie stanowi również dobre narzędzie doskonalenia profesjonalnej wiedzy z zakresu etyki.

Możemy bowiem skupić się na problemie wyboru narzędzi etycznych do rozwiązywania studium przypadku. Wtedy z jednej strony staramy się znaleźć normy będące podstawą wydawanych sądów moralnych, z drugiej zaś jesteśmy zainspirowani do prowadzenia analiz metaetycznych badających uzasadnienie proponowanych teorii etycznych i norm służących do rozwiązywania zagadnień z zakresu studium przypadku.

Również ważnym doświadczeniem dla etyków, zamykających się często w sferze rozważań teoretycznych, stanowi doświadczenie zastosowania praktycznego, teoretycznego dorobku etyki.

Szczególnie cenne jest zbadanie możliwości stosowania zasady uniwersalizacji w przypadkach opierania się $\mathrm{w}$ analizach etycznych dotyczących wydarzeń w sferze gospodarczej na imperatywie kategorycznym I. Kanta. Często bowiem podnoszony 
jest nie w pełni słuszny zarzut, iż stosowanie imperatywu kategorycznego jest ograniczone, gdyż problemem staje się pogodzenie wymogu uniwersalizacji z występującymi w biznesie sytuacjami, które wydają się być tak indywidualne, że trudno sobie wyobrazić sens tworzenia na ich podstawie maksymy postępowania potrzebnej do oceny etycznej działania.

Dla poparcia tego zarzutu powołuje się na dorobek Nicolai Hartmanna, który jak nikt inny rozumiał potrzebę indywidualnej ekspresji i tworzenia własnej skali wartości, głosił bowiem potrzebę odważnej realizacji własnych planów życiowych zgodnie ze specyficznym dla siebie, niepospolitym postępowaniem.

Według niego istnieje imperatyw rozwoju własnej osobowości. Człowiek jako działająca osobowość „musi raczej zarazem chcieć, by [...] było w jego postępowaniu jeszcze coś własnego, czego zamiast niego nikt inny nie mógłby i nie powinien czynić. Jeśli z tego zrezygnuje, staje się zwykłym, zastępowalnym przez każdego numerem w tłumie: jego osobista egzystencja staje się daremna, bezsensowna". ${ }^{6}$

Ekspresja indywidualności właśnie w przypadku gospodarki prowadzi do innowacyjnych rozwiązań, jednak ich wartość musi zawsze być oceniana ze względu na skutki, jakie przynosi. Sama innowacyjność przyczyniająca się do sukcesu finansowego nie wystarczy, byśmy mogli powiedzieć o kimś, że „dobrze zarabia”.

Jak pisze Nicolai Hartmann „każdy konkretny człowiek winien »być« według swojego indywidualnego etosu; powinien go wypełniać swoim byciem. Nie powinien jednak tego czynić kosztem wartości powszechnych, lecz raczej w tych granicach, w jakich pozwalają mu one działać, granice te są jednak rozległe [...]. We wszelkiej moralności wartości powszechne mają charakter podstawy i w tym sensie mają bezwzględne pierwszeństwo. Dopiero nad nimi może się wznosić bardziej zróżnicowana struktura osobistego wartościowego bycia".

Tym samym głębsza, etyczna analiza ukazuje nam możliwość stosowania imperatywów I. Kanta nawet w sytuacji, gdy działanie ma na wskroś indywidualny charakter. Tym bardziej ważne jest to stwierdzenie, iż mylnie się przypuszcza, że I. Kantowi chodziło o ocenę działania wedle zasady: „Co by było, gdyby wszyscy tak czynili”.

Prawdą jest natomiast, że I. Kant klasyfikował działania jako moralne wtedy, gdy stworzone na ich podstawie maksymy nie zaprzeczają prawu powszechnemu, czyli nie negują m.in. prawa ochrony własności w czasach I. Kanta, a obecnie prawa wolnej konkurencji.

\footnotetext{
${ }^{6}$ N. Hartmann, Wypisy z etyki, wybór i oprac. M. Grabowski, Wydawnictwo UMK, Toruń 1999, s. 78.

7 Ibidem, s. 82.
} 
Również w toku refleksji etycznej i metaetycznej prowadzonej nad analizą etyczną dokonaną w studium przypadku etycy mają szanse praktycznego ustosunkowania się do przydatności różnych odmian konsekwencjalizmu, w tym utylitaryzmu.

Zastosowanie konsekwencjalizmu jako metody oceny etycznej decyzji gospodarczych ma swoje poważne ograniczenia. Konsekwencjalizm wydaje ocenę na podstawie założenia, że intencje, zamiary doprowadzą w przyszłości do przewidywanych skutków. Jednakże decyzja, którą mamy podjąć, choć może mieć jako podstawę wysoce moralne intencje, może prowadzić do powstania skutków, które często zależą od czynników nie do przewidzenia. Szczególnie w działaniach gospodarczych mamy do czynienia z dużym stopniem ryzyka polegającego na tym, że nasze zamiary nie zrealizują się po naszej myśli lub wywołają nieoczekiwane skutki. Dlatego powoływanie się na to, iż działanie jest dobre moralnie, ponieważ przyniesie ono dobre rezultaty, np. jak głosi utylitaryzm w postaci szczęścia jak największej liczby ludzi, jest niewystarczające do akceptacji moralnej. Na podstawie tej argumentacji nie możemy dokonać wyboru właściwego sposobu działania.

Możemy jednak w trakcie analizy etycznej studium przypadku z zakresu etyki biznesu starać się udowodnić potrzebę stosowania bezwarunkowo reguły konsekwencjalistycznej Marcusa G. Singera. Głosi ona, że: „iż nie należy podejmować żadnych działań, których powszechne podjęcie przyniosłoby złe skutki” bez wyjątków, nawet wtedy, gdy wydaje się nam, że podjęliśmy je pod wpływem okoliczności tylko raz.

Tym samym cenne dla etyków podejmujących się trudu rozwiązywania kwestii zawartych w studium przypadku z zakresu gospodarki jest potwierdzenie, a dla studentów nabycie przeświadczenia o potrzebie bezwzględnego zachowania podstawowych norm i zasad i uświadomienie potrzeby podjęcia się trudu stopniowego dochodzenia do pełnego przestrzegania wskazań etycznych w życiu zawodowym i w samej organizacji.

Studium przypadku zatem stanowi bardzo ważne z etycznego i moralnego punktu widzenia doświadczenie pozwalające na odpowiedź na pytania: Jak zachowywać się właściwie w sytuacji, gdy nie ma szans na spełnienie wymogów wypływających $\mathrm{z}$ wszystkich norm moralnych.

${ }^{8}$ M.G. Singer, Verallgemeinerung in der Ethik: zur Logik moralischen Argumentierens, Suhrkamp Verlag, Berlin 1975, s. 30. 


\section{Przykłady studium przypadku z zakresu etyki biznesu}

\section{Przykład 1}

Niespełna rok temu w rodzinnej miejscowości wykupiłeś dzięki kredytom stare forty. Umieściłeś w nich magazyn wyrobów spirytusowych, które sam produkujesz. Dzięki twojej inicjatywie kolejnych 10 osób znalazło pracę w regionie trapionym przez bezrobocie. Interes rozwijał się pomyślnie. Mimo spłat dużych rat kredytów dokończyłeś budowę domu i byłeś w stanie posłać swoje dzieci do prywatnej szkoły.

Właśnie wracasz ze spotkania absolwentów twojego liceum. Wszyscy cię chwalili nie tylko za pomysłowość, ale - co tu dużo ukrywać - za jakość wódki, którą ze sobą przywiozłeś.

Wróciwszy do domu w nadzwyczaj dobrym humorze, już miałeś zamiar się położyć, gdy zadzwonił kolega dziennikarz, który nie przybył na spotkanie absolwentów. To, co ci powiedział, otrzeźwiło cię zupełnie!

Mianowicie, dzisiaj rano jeden z jego kolegów przyniósł sensacyjny materiał o tym, jak policja wykryła fałszerzy najlepszej z wódek, którą produkujesz. Co gorsza, jej spożycie grozi dużymi komplikacjami zdrowotnymi.

Kolega dziennikarza chce za trzy dni poinformować kolegium redakcyjne o całej sprawie. Jak masz postąpić?

Krótki komentarz do przykładu 1. Jego specyfika polega przede wszystkim na podjęciu próby zgodnego z normami i zasadami etycznymi rozwiązania szczególnie niebezpiecznej sytuacji dla klientów, ale i firmy i jej właściciela. Jakie zatem należy przedstawić argumenty etyczne, by oddalić pokusę najprostszego rozwiązania, które jednak łamie wszelkie zasady etyczne?

\section{Przykład 2}

W ostatnim czasie nie wiodło ci się dobrze. Zachodnia firma, w której byłeś zatrudniony, wycofała się z polskiego rynku. Masz do spłacenia wiele zobowiązań finansowych i na domiar złego twoja żona musi w najbliższym czasie poddać się kosztownej operacji. Po miesiącach poszukiwań pracy udało ci się dostać do zarządu grupy kapitałowej finansującej duże inwestycje. Musisz wykazać się na początek jakimś spektakularnym osiągnięciem. Właśnie masz taką możliwość. Wpadłeś na pomysł, iż konsorcjum, w którym pracujesz, zainwestuje swój kapitał w finansowanie budowy wielkich hal targowych. Masz już zatwierdzone środki finansowe. Pozostały rozmowy z inwestorami. W ich trakcie dowiadujesz się, iż środki finansowe są za małe na realizację projektu. Dzięki rozmowie z inwestorem docierasz 
do głównego projektanta hal targowych. Jest nim doświadczony i znany architekt. To za jego sprawą wzrosły niepomiernie koszty inwestycji. Z rozmowy z nim dowiadujesz się, iż zwiększył on parametry konstrukcyjne budowli ponad przyjęte standardy budowlane w Europie Zachodniej. Tłumaczył to faktem, iż w Polsce są inne warunki klimatyczne. Niekiedy zdarzają się duże opady śniegu, co może doprowadzić do ogromnych obciążeń dachu i konstrukcji nośnej. Wiesz, że jego stanowisko uniemożliwia realizację pomysłu inwestycyjnego. Od specjalistów prawa budowlanego dowiedziałeś się, iż regulacje prawne nie obejmowały tak wielkich obiektów, ale można trzymać się przepisów budowlanych dla mniejszych inwestycji i nie stosować zawyżonych norm. Co zrobisz w tej sytuacji?

Krótki komentarz do przykładu 2. To studium przypadku prowadzi nas do rozważenia różnych rodzajów odpowiedzialności: względem rodziny, względem własnego postępowania, względem własnej firmy, ale przede wszystkim szczególnie wobec przyszłych użytkowników.

\section{Przykład 3}

Jesteś dyrektorem średniej wielkości firmy budowlanej, która stale ma problemy z uzyskiwaniem wystarczającej ilości zamówień publicznych. Dzisiaj rano przeglądałeś pocztę elektroniczną. Twoją uwagę zwrócił list dawnych kolegów z klubu ekologicznego. Dowiedziałeś się z niego, że Agencja do spraw Ochrony Środowiska ONZ uznała Wisłę za jedną z pięciu ostatnich dzikich rzek Europy i jeden z głównych korytarzy ekologicznych kontynentu. Wzdłuż jej biegu przemieszczają się zwierzęta i rośliny. Zaniedbania w jej regulacji (wybudowano tylko jeden stopień wodny we Włocławku zamiast planowanych ośmiu) pozwoliły ocalić unikalne w skali globu naturalne biotopy łęgowe zamieszkałe przez rzadkie gatunki ptaków i endemity roślinne. Wiesz coś o tym, bo kiedyś w upalny dzień wybrałeś się z synem w okolice Płocka. Do dzisiaj w pamięci masz obraz tamtych stron. Na zdjęciach widać was uśmiechniętych i beztroskich. Brak regulacji w sposób przewrotny doprowadził do poprawy czystości wody, natomiast wiesz, że szybki bieg uregulowanej rzeki nie pozwoli na jej samooczyszczenie. Dlatego przeciw regulacji już teraz protestują ekolodzy.

Jednakże przeglądając dalej pocztę elektroniczną, przeczytałeś drugi list od kolegów z branży. Mówił on o raporcie Ministerstwa Ochrony Środowiska i Zasobów Wodnych. Dowiedziałeś się z niego, że nieuregulowanie Wisły doprowadziło do realnej możliwości katastrofy. Otóż tama we Włocławku pełni od trzydziestu lat zadania, które miały przejmować niewybudowane osiem stopni wodnych. Według wstępnych obliczeń z powodu możliwości pęknięcia tamy bezpośrednio zagrożonych jest 200 osób, a dalsze 2 tys. może ucierpieć podczas wielkiej powodzi. Co gorsza, 
awaryjne opróżnienie zbiornika we Włocławku grozi przedostaniem się do Wisły gromadzonych od lat na dnie trucizn. Rozwiązaniem wydaje się budowa stopnia wodnego w Nieszawie. Na jego utworzenie silnie nalegają też przedstawiciele lobby energetycznego. Wskazują oni na wielkie korzyści ekonomiczne związane z zainstalowaniem turbin prądotwórczych. Sama budowa i eksploatacja nowej tamy da pracę wielu ludziom w tym regionie odczuwającym skutki bezrobocia. Także ty możesz liczyć na zamówienia.

Wszyscy mają świadomość, że związana z budową regulacja zmieni charakter rzeki. Dla jednych upodobni ją do rzek europejskich, po których mkną barki, a dla drugich oznacza jej bezpowrotne zniszczenie.

Już dzisiaj zastanawiasz się, jakie stanowisko zajmie rząd. Jak uzasadni swoją decyzję? I czy ty, który kiedyś z sympatią towarzyszyłeś akcjom ekologów, a obecnie jesteś menedżerem średniej wielkości firmy budowlanej, będziesz starał się wpłynąć na decyzje w sprawie budowy i czy masz zabiegać o ewentualne kontrakty?

Krótki komentarz do przykładu 3. Mamy tu do czynienia z konfliktem wartości, i to szczególnym, który przekształca się w dylemat moralny, gdyż racje co do wyboru właściwej drogi postępowania są podzielone.

\section{Przykład 4}

Cały świat wraz z nastaniem roku 2000 chciał wkroczyć w nową epokę. Europejskie banki mające silne ograniczenia w dziedzinie inwestowania wyraźnie nie dotrzymywały kroku amerykańskim korporacjom finansowym. Zdecydowano się na nową strategię aktywnego wkraczania na nowe rynki finansowe i obracania turbofinansowymi produktami, wydawało się zresztą, że nie ma innej możliwości. Na rynku finansowym panuje bowiem, jak głosili zwolennicy nowej strategii, prosta zasada: walcz albo zgiń. Właśnie wtedy wyjechałeś na praktykę bankową do Frankfurtu nad Menem.

Twoim pierwszym zadaniem było doradztwo i sprzedaż nowych wtedy produktów inwestycyjnych o wdzięcznej nazwie: złożone instrumenty pochodne oparte na długu (collateral debt obligations - CDO). Na początku chciałeś dorównać wynikami sprzedaży swym niemieckim kolegom. W odróżnieniu jednak od nich, „starych wyjadaczy" zamierzałeś zdobyć trochę informacji o oferowanych produktach. To, czego się dowiedziałeś, wzbudziło twój niepokój.

Otóż te wysoko skomplikowane produkty były oparte na warstwowo spakowanych kredytach, wśród których były kredyty subprime.

W tym czasie masowo były bowiem zaciągane kredyty hipoteczne częściowo na kupno własnego domu, a częściowo pod zastaw spłacanej hipoteki, w celu kupna nowych nieruchomości. Wszystko odbywało się zgodnie z logiką rynkową. Ceny 
nieruchomości rosły w szalonym tempie i wydawało się, że każdy będzie mógł spłacić kredyt i dużo zarobić, a jak nie uda mu się tego dokonać, to bank przejmie nieruchomość i sprzeda ją z zyskiem. Ponieważ banki nie mogły prowadzić nieograniczonej akcji kredytowej, bo obowiązywały je ustawy branżowe, to powoływano firmy zależne, zwane biurami kredytowymi, które działały zupełnie legalnie. Do jednej $\mathrm{z}$ nich należała największa amerykańska firma pożyczkowa Ameriquest. Skoro rentowność firm i dochody pracowników były uzależnione od ilości sprzedawanych kredytów, udzielano ich wszystkim chętnym, nie martwiąc się o zdolności kredytowe klientów. Również agencje ratingowe, w których praca była dla ciebie jednym z niespełnionych jeszcze marzeń, wydawały najwyższą ocenę AAA produktom finansowym, których sprzedaży masz się podjąć.

Zaczęły jednak trapić cię wątpliwości, co się stanie, gdy nagle ceny nieruchomości przestaną rosnąć. Oczywiście nawet uczeń liceum wiedział, że w tym momencie kredytobiorcy nie będą w stanie spłacić swych kredytów zaciągniętych na inwestycje w nieruchomości. Zresztą i bez spadku cen nieruchomości udzielanie kredytów na nabywanie nieruchomości osobom ledwo utrzymującym się z swojej pensji było dla ciebie wielce podejrzane.

Kiedy przy piwie podzieliłeś się wątpliwościami ze swoimi kolegami, oni tylko wzruszyli ramionami i stwierdzili, że wszyscy tak robią i w przypadku hipotetycznego załamania rynku nieruchomości państwo na pewno wszystkim pomoże, a teraz od każdego sprzedanego produktu finansowego typu loan otrzymujemy realne pieniądze. Jednakże dalej trapiły cię wątpliwości. Zadzwoniłeś do szefa polskiego banku, który wysłał cię na praktyki.

Zastanów się, co odpowie szef banku na twe wątpliwości.

Krótki komentarz do przykładu 4. Ten przykład ukazuje nam całą wagę prowadzenia analizy etycznej procesu decyzyjnego. Działanie, które ma być podjęte, jest legalne, staje się powszechną, uznaną przez środowisko praktyką, aczkolwiek na pierwszy rzut oka budzi wątpliwości moralne.

\section{Przykład 5}

Wiadomo, iż nikt nie chce płacić zbyt wysokich podatków. Dlatego im większe są dochody indywidualne czy też firmy, tym chętniej sięgamy do różnych sposobów zmniejszania obciążeń podatkowych.

W filmie pod tytułem „Firma” w reżyserii Sydneya Pollacka (1993) mentor młodego prawnika wprowadzanego w praktykę doradcy podatkowego powiada: „Zastanów się, jaka jest właściwie różnica pomiędzy unikaniem płacenia podatków a uchylaniem się od nich". Przedstawia on do wyboru trzy odpowiedzi:

„1) Różnica powstaje w wyniku decyzji urzędu skarbowego. 
2) Określa tę różnicę sprytny prawnik.

3) Różnicę wyznacza sąd, dając 10 lat za niepłacenie podatku”.

W dalszej części filmu mentor młodego prawnika stwierdza: „Zawód doradcy podatkowego nie ma nic wspólnego z prawem. To jest rodzaj gry. Tej gry uczymy bogatych, aby nie stracili swoich majątków. Kiedy urząd skarbowy zmienia zasady, wtedy my zarabiamy na tym, ucząc ludzi bogatych, jak mają na nowo uniknąć podatków, zatem to tylko gra".

Jednakże w klasyfikacji prawnej mamy od czynienia z dwoma rodzajami zmniejszania opodatkowania: unikania opodatkowania, które jest legalne, i uchylania się od podatków, która to czynność łamie prawo.

Zbadaj, czym są w świetle tej klasyfikacji prawnej powszechnie stosowane praktyki zmniejszania opodatkowania:

1) Oferowane przez banki obchodzenie „podatku Belki”, który nakładał konieczność odprowadzenia 19\% z zysku z akcji giełdowych, funduszy i lokat bankowych.

2) Zachęcanie przez doradców podatkowych rejestracji firm w rajach podatkowych.

3) Popularne w latach dziewięćdziesiątych zakładanie fundacji w celu zmniejszania opodatkowania.

Następnie dokonaj oceny moralnej tych działań. Czy wszystkie przypadki legalnego zmniejszania opodatkowania są moralnie dopuszczalne?

Jak ocenisz moralnie postawę, którą zajmuje w sprawie zmniejszania opodatkowania mentor świeżo upieczonego doradcy podatkowego?

Krótki komentarz do przykładu 5. Jest to przykład diagnostycznego studium przypadku. Wymaga ono zebrania materiałów na temat zjawiska zmniejszania opodatkowania, w tym dotarcia do orzecznictwa sądowego dostępnego np. w internecie, i na tej podstawie zakwalifikowania danych zjawisk z prawnego punktu widzenia, a dopiero na końcu przedstawienie uzasadnienia etycznego własnego osądu moralnego na temat tych czynności.

\section{Case study as a method of teaching business ethics. The origins of business ethics case studies}

The Harvard Business School introduced the practice of teaching business ethics through case study. This article presents the characteristics of teaching business ethics through case study. First we answered the question: how to build a case study? Then we showed how moral problems are solved through a case study. Next we showed the types of case study (teaching goal, kind of moral issues, the 
role of ethics and problems of this method of teaching). Then we answered the question how to use the methods of philosophy for the analysis of case study. We have considered the problem of the moral level of the students who solved the case study. Turning to practical matters provides instructions for building a case study. Finally, we showed that solving the case study not only provides a valuable method of teaching ethics in the business, but is valuable for professional ethics.

\section{L'étude de cas comme une méthode d'enseignement de l'éthique des affaires. L'origine des études de cas en éthique des affaires}

Harvard Business School a introduit la pratique de l'enseignement de léthique des affaires à travers létude de cas. Larticle présente les caractéristiques de cette méthode. Nous avons d'abord répondu à la question de savoir comment construire une étude de cas? Ensuite, nous avons montré comment les problèmes moraux sont résolus grâce à une étude de cas. Cela a conduit à identifier les types de létude de cas à la base du critère de l'objectif éducatif, du type de problème moral et du rôle de léthique. Les problèmes soulevés par cette méthode d'enseignement ont été étudiés. Ensuite, nous avons indiqué la possibilté d'utiliser des méthodes de la philosophie pour analyser une étude de cas et nous avons mis l'accent sur la corrélation entre le niveau moral des personnes qui entreprennent l'analyse éthique de létude de cas et les solutions possibles du problème étudié. Enfin, nous avons montré que l'étude de cas est une méthode valable d'enseignement de léthique des affaires et joue un rôle important pour les éthiciens en montrant si certaines théories sont possibles à mettre en pratique dans la vie économique. 